\title{
Antifungal Effect of Kaffir Lime Leaf Extract on Selected Fungal Species of Pathogenic Otomycosis in in vitro Culture Medium
}

\author{
Mohd Syafwan Soffian', Irfan Mohamad ${ }^{1 *}$, Zeehaida Mohamed ${ }^{2}$, Rosdan Salim ${ }^{1}$ \\ 'Department of Otorhinolaryngology-Head \& Neck Surgery, School of Medical Sciences, Universiti Sains Malaysia Health Campus, 16150 Kota Bharu, Kelantan, MALAY- \\ SIA. \\ 2Department of Medical Microbiology \& Parasitology, School of Medical Sciences, Universiti Sains Malaysia Health Campus, 16150 Kota Bharu, Kelantan, MALAYSIA.
}

\begin{abstract}
Background: Kaffir lime (Citrus hystrix D.C) has been used for a long time in agricultural and alternative medicine. Kaffir lime leaf (KLL) had been proved effective against certain fungi that could infect human body. Objective: To study the antifungal effect of KLL extracts on Aspergillus niger and Candida albicans. Methods: This is a laboratory-controlled prospective study conducted in Universiti Sains Malaysia. KLL was extracted with $70 \%$ ethanol and aqueous via Soxhlet extraction method. The concentrated extract then freeze dried to obtain powdered form which was diluted to establish five different concentrations of $50 \mathrm{~g} / \mathrm{ml}, 25 \mathrm{~g} / \mathrm{ml}, 12.5 \mathrm{~g} / \mathrm{ml}, 6.25 \mathrm{~g} / \mathrm{ml}$ and 3.125 $\mathrm{g} / \mathrm{ml}$. Sabouraud Dextrose Agar (SDA) lawned with tested fungal isolates were inoculated with the extracts using well-diffusion method. Zone of inhibition was measured followed by minimum inhibitory concentration (MIC). Results: There were presences of zone of inhibition for both aqueous and alcohol KLL extracts on Aspergillus niger and Candida albicans growth. $\mathrm{KLL}$ aqueous extract have bigger mean of inhibition as compare to alcohol extract against Aspergillus niger. In contrast, KLL alcohol extract have bigger mean of inhibition as compare to aqueous extract against Candida albicans. The MIC of KLL aqueous extract against Candida albicans was $12.02 \mathrm{~g} / \mathrm{ml}$, alcohol extract against Candida albicans was $10.23 \mathrm{~g} / \mathrm{ml}, \mathrm{KLL}$
\end{abstract}

aqueous extract against Aspergillus niger was $47.86 \mathrm{~g} / \mathrm{ml}$ and alcohol extract against Aspergillus niger was $48.97 \mathrm{~g} / \mathrm{ml}$. Conclusion: KLL has significant antifungal effect towards pathogenic fungi causing otomycosis, particularly Aspergillus niger and Candida albicans.

Key words: Otomycosis, Kaffir lime, Citrus hystrix, Aspergillus niger, Candida albicans.

Key message: Statistically antifungal activity of Aspergillus niger is better in aqueous extracts as compared to alcohol extract. In contrast, antifungal activity of Candida albicans is better in alcohol extracts as compared to aqueous extract. Candida albicans was inhibited better as compared to Aspergillus niger in both aqueous and alcohol KLL extract.

Correspondence :

Dr Irfan Mohamad, Associate Professor, Department of ORL-HNS, School of Medical Sciences Universiti Sains Malaysia, Health Campus-16150 Kota Bharu, Kelantan, MALAYSIA.

Phone: 609-7676420

Email: irfankb@usm.my

DOI: 10.5530/jyp.2017.9.92

\section{INTRODUCTION}

Kaffir lime (Citrus hystrix D.C) has been used for a long time in folk medicine. ${ }^{1}$ Preclinical studies have shown that the phytochemicals compound of kaffir lime leaf (KLL) and fruit have antioxidant activity, ${ }^{2}$ free radical scavenging ability, ${ }^{2}$ anti-inflammatory activity, ${ }^{3}$ antibacterial activity, ${ }^{4}$ antifungal activity, ${ }^{1-5}$ and anticarcinogenic activity. ${ }^{6}$

Phytochemical studies have shown that citronellal is the main compound found in KLL. ${ }^{7}$ Other chemical compounds include a-pinene, camphene, b-pinene, limonene, copaene, linalool, b-cubebene, isopulegol, caryophyllene, citronellyl acetate and citronellol. ${ }^{8}$ Research shows that citronellal has strong antifungal qualities. ${ }^{9}$

Otomycosis or fungal infection of the external auditory canal can be caused by Aspergillus niger, Aspergillus fumigatus, Aspergillus flavus, Candida albicans, Mucor spp. and Penicillium spp. ${ }^{10}$ Malaysian data on fungal isolates in otomycosis revealed that Aspergillus niger was the commonest isolated fungi (71\%) and Candida albicans was the second most common (23.4\%). ${ }^{11}$

Aspergillus niger able to produce several secondary toxic metabolites such as 3-nitropropionic acid and ochratoxin A. ${ }^{12}$ In contrast, cell surface hydrophobicity, biofilm formation and adhesion composite resin process are the important factors in defence mechanism of Candida albicans. ${ }^{13}$ The importance of this character is a reduced susceptibility to the host immune system and to conventional antifungal drug therapy. ${ }^{13}$

Eradication of this entity remains a challenge to medical practitioners especially the otorhinolaryngology. Until today, there has been no standardised treatment for otomycosis. ${ }^{14}$ Minimal data is available regarding safety of use of ototopical medication especially in presence of tympanic perforation. ${ }^{15}$ In a case of perforated tympanic membrane, the topical antifungal can readily reach cochlea by diffusion through the round window. If the agent has ototoxic property, temporary and permanent electrophysiology changes within inner ear or morphological injury to stria vascularis, hair cells and supporting cells of organ of corti may occur. This situation can lead to ototoxicity and sensory neural hearing loss. ${ }^{14,15}$

When choosing the correct topical antifungal drugs, certain factors should be considered such as water soluble, low risk of ototoxicity, low allergic effect, a broad spectrum antimitotic drug, suitable for application on pediatric patients, and commercially available. ${ }^{15}$ There were very limited publications on antifungal effect of KLL especially to Candida albicans and Aspergillus niger. Hence, in this study, we are considering the antifungal properties of KLL extracts towards pathogenic otomycosis, particularly Aspergillus niger and Candida albicans.

\section{METHODOLOGY}

\section{Study design}

This is a laboratory-controlled prospective study. It was fully conducted under a well-controlled environment in the Medical Microbiology and Pharmacology laboratories in the School of Medical Sciences, Universiti 
Sains Malaysia (USM). This study has been approved by the Human Ethics Committee of USM.

Extracts from KLL will be isolated using two different solvents which is aqueous and alcohol. Each extract is diluted into five different concentrations and test to five replicates of fungal cultures. Thus, one type of fungal culture is used for five separate concentrations and one fungal culture test with two types of solvents which ended up to ten samples. Therefore, 50 samples are tested for five replicates in standard laboratory settings. Total sample for two types of fungal culture was 100 samples. ${ }^{16}$

\section{Sample preparation}

KLL were collected from a single area, prepared for USM herbarium identification (voucher reference number 11538). The remaining KLL were washed with distilled water and dried in oven at $45^{\circ} \mathrm{C}$ for two days. Dried KLL leaves should maintain the original green colour. Then, the dried leaves were grinded using leaf grinder machine to smaller course powder form and stored in tightly sealed glass container.

\section{Sample extraction}

The method of choice for extraction was the Soxhlet extraction by using Soxhlet apparatus. This uses a solvent for extraction and at completion the solvent will be fully removed. We used two types of solvent, which was aqueous and ethanol $70 \%$. The dried powder form of the tested leaves was inserted into the Soxhlet thimble and closed with white thin gauze. The thimble was inserted into the Soxhlet main chamber and closed. The solvent chamber was filled with ethanol 70\% 1 litre, and attached to Soxhlet apparatus. Solvent chamber should not be overfilled and the volume of solvent in the vessel should be 3 to 4 times the volume of the Soxhlet chamber. The solvent chamber was heated and solvent vapour travels up a distillation arm, and fills into the main Soxhlet chamber. The condenser ensures that any solvent vapour cools, and drips back down into the chamber housing the powder. Some of the desired compound was then dissolved in the warm solvent. When the Soxhlet chamber was almost full, the chamber was automatically emptied by a siphon side arm, with the solvent running back down to the distillation flask. This extraction allowed for 4-6 cycles. By $6^{\text {th }}$ cycle, the solvent chamber was dark in colour and Soxhlet chamber was clearer. The solvent with desired compound was extracted and in solvent chamber. The extracted leaves in alcohol solvent then evaporated with rotary evaporator. The volume of extract was concentrated till $50 \mathrm{ml}$ and inserted into multiple sterile containers. It was freeze dried to avoid further heat damage on a freeze dryer machine. For water solvent, same process done whereby the ethanol was replaced with distilled water in solvent chamber.

This powder form extracts were used to establish different concentrations as required in this study. The concentrations required were $50 \mathrm{~g} / \mathrm{ml}$, $25 \mathrm{~g} / \mathrm{ml}, 12.5 \mathrm{~g} / \mathrm{ml}, 6.25 \mathrm{~g} / \mathrm{ml}$ and $3.125 \mathrm{~g} / \mathrm{ml}$. Initial $100 \mathrm{~g}$ mixed with two $\mathrm{ml}$ of distilled water to produce $50 \mathrm{~g} / \mathrm{ml}$ concentration. Then one $\mathrm{ml}$ from the $50 \mathrm{~g} / \mathrm{ml}$ concentration taken and distilled water added till two $\mathrm{ml}$ level to make $25 \mathrm{~g} / \mathrm{ml}$ concentration. Similarly, one $\mathrm{ml}$ was taken from $25 \mathrm{~g} / \mathrm{ml}$ concentration to make up $12.5 \mathrm{~g} / \mathrm{ml}$. The dilution continued till $3.125 \mathrm{~g} / \mathrm{ml}$ concentration. The left-over extracts were discarded and a new preparation done for new replicates.

\section{Preparation of in vitro culture medium}

The fungal isolates were taken from archives of microbiology laboratory in School of Medical Sciences, USM, which already been identified earlier from patients of otorhinolaryngology clinic. Both Candida albicans and Aspergillus niger was used as tested fungi. Candida albicans from SDA plates were suspended in sterile distilled water and adjust to $10^{6}$ cells with colony forming units $(\mathrm{CFU}) / \mathrm{ml}^{9}(0.5 \mathrm{McF}$ arland standard). Nephelometer was used to adjust the turbidity of fungal suspensions so that the number of fungal was within a given standard McFarland range. Similar process done for Aspergillus niger.

The suspended sterile fungal organism labelled and used for the next step to lawn and prepare for testing in SDA plates. Within 15 min of diluting the organism, sterile swab was dipped into the properly adjusted inoculums of tested fungal organism. The sterile swab was slightly lifted, and then the swab was firmly rotated several times against the upper inside wall of the tube to express excess fluid. The plate was open slightly to lawn the fungal organism. Later, by using glass pipette, four wells were created in four quadrants.

\section{Initiation of in vitro test and data collection}

The SDA plate was kept lid side up in a $30^{\circ} \mathrm{C}$ incubator. Before inserting in an incubator, micropipette was used to drop 100 microliters of extracts into wells. The upper quadrant well, the aqueous KLL extract was inserted with its aqueous control at opposite site. The lower quadrant well, the alcohol extracts was inserted with its alcohol control at opposite site (Figure 1A \& 1B). This was done using different concentration which was diluted prior to this. Five different replicates were done. The plates were examined every day to make sure no spillage or growth of other organism. The measurement was done on third day whereby this was the perfect time to visualize the margin of inhibition. After the third day, there was overgrowth especially the Aspergillus niger which may jeopardize the safety of the staff. Measurement was done of zones showing complete inhibition by gross visual inspection.

\section{Determination of minimum inhibitory concentration (MIC)}

Minimum inhibitory concentration measured by agar diffusion method to determine MIC of each tested KLL extracts. After measurement of all the result, a scattered plot graph $\mathrm{X}^{2}$ Versus Log Concentration was plotted. A linear line represents the mean value was drawn and the area where $\mathrm{X}^{2}$ equal to zero was taken for the MIC level of the extract. Antilog of the selected value was mathematically identified as MIC. The $\mathrm{X}$ value represent the zone of inhibition diameter subtract the well diameter and divided by two.

\section{RESULTS}

Zone of inhibition which is the clear zone where growth of fungal does not occurred was measured for each tested KLL extracts. There was zone of inhibition for both aqueous and alcohol KLL extracts after three days of incubation on Candida albicans. Similarly, Aspergillus niger growth was inhibited in aqueous and alcohol KLL extracts. However, not all concentrations of extracts effectively inhibited the growth in both pathogens. Aspergillus niger was inhibited only in the highest concentration at $50 \mathrm{~g} / \mathrm{ml}$ in both aqueous and alcohol KLL extracts. All samples revealed negative control (wells contain either only alcohol or only aqueous) showed no zone of inhibition against Aspergillus niger and Candida albicans.

\section{Inhibitory efficacy of kaffir lime leaf on Aspergillus niger}

Aspergillus niger showed sensitivity to both aqueous and alcohol KLL extracts (Table 1A). Growth of Aspergillus niger inhibited in KLL alcohol and aqueous extract in concentration of $50 \mathrm{~g} / \mathrm{ml}$. However, the growth was resistance to concentration from $25 \mathrm{~g} / \mathrm{ml}, 12.5 \mathrm{~g} / \mathrm{ml}, 6.25 \mathrm{~g} / \mathrm{ml}$ and $3.125 \mathrm{~g} / \mathrm{ml}$. One replicate of samples at different concentrations whereby aqueous KLL extract tested at right upper quadrant of petri dish and alcohol KLL extract tested at left upper quadrant of each petri dish (Figure 2A). Mean zone of inhibition is higher in extract concentration of aqueous compared to alcohol. 


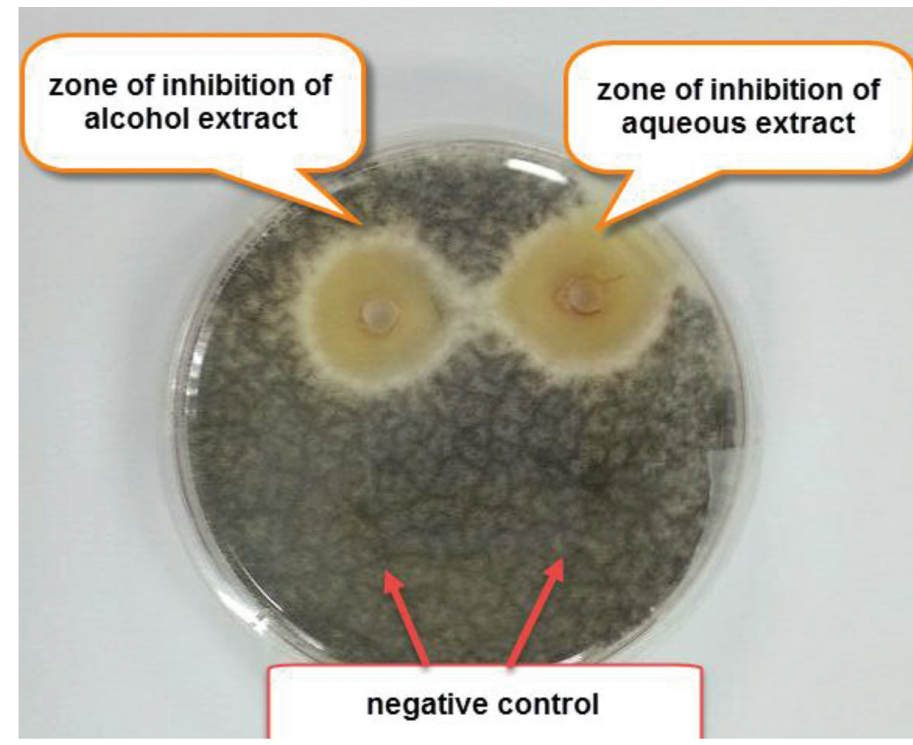

Figure 1A: Positive zone of inhibition against Aspergillus niger with negative control in kaffir lime leaf aqueous and alcohol extracts at $50 \mathrm{~g} / \mathrm{ml}$ concentration.

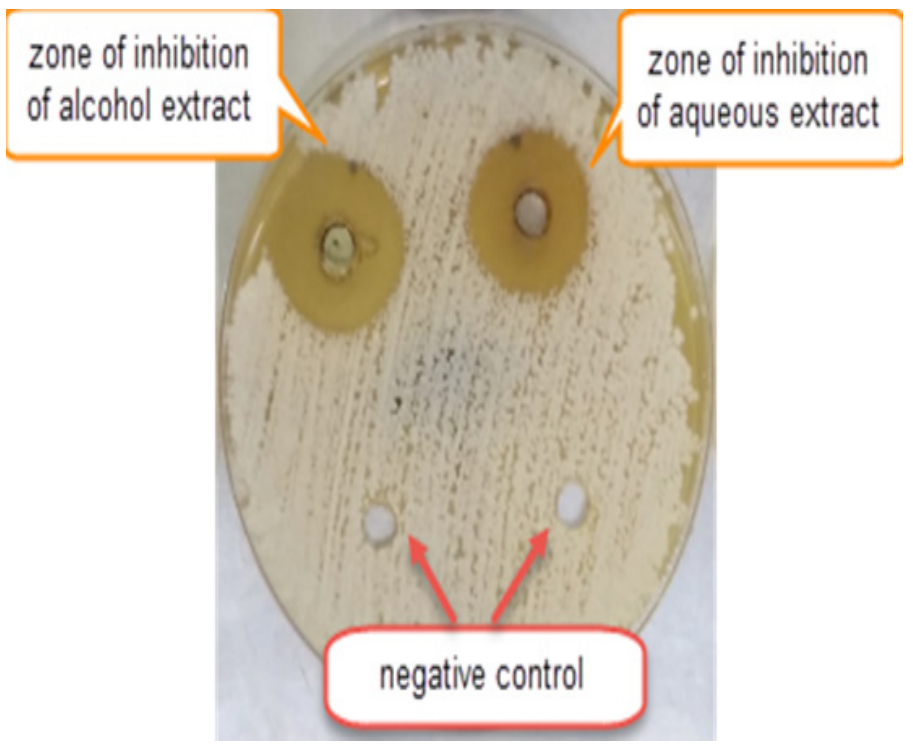

Figure 1B: Positive zone of inhibition against Candida albicans with negative control in aqueous and alcohol extract at $12.5 \mathrm{~g} / \mathrm{ml}$ concentration.

Table 1A: Measurement of zone of inhibition of alcohol and aqueous kaffir lime leaf extracts on Aspergillus niger growth at five different concentrations

\begin{tabular}{|c|c|c|c|c|c|c|c|}
\hline \multirow[t]{2}{*}{ Extracts } & \multirow[t]{2}{*}{ Concentration $(\mathrm{g} / \mathrm{ml})$} & \multicolumn{5}{|c|}{ Zone of Inhibition (mm) } & \multirow[t]{2}{*}{ Mean (mm) } \\
\hline & & R1 & R2 & R3 & R4 & R5 & \\
\hline \multirow[t]{5}{*}{ Aqueous } & 50.000 & 14 & 13 & 14 & 14 & 15 & 14.00 \\
\hline & 25.000 & 0 & 0 & 0 & 0 & 0 & .00 \\
\hline & 12.500 & 0 & 0 & 0 & 0 & 0 & .00 \\
\hline & 6.250 & 0 & 0 & 0 & 0 & 0 & .00 \\
\hline & 3.125 & 0 & 0 & 0 & 0 & 0 & .00 \\
\hline \multirow[t]{5}{*}{ Alcohol } & 50.000 & 10 & 12 & 12 & 11 & 12 & 11.40 \\
\hline & 25.000 & 0 & 0 & 0 & 0 & 0 & .00 \\
\hline & 12.500 & 0 & 0 & 0 & 0 & 0 & .00 \\
\hline & 6.250 & 0 & 0 & 0 & 0 & 0 & .00 \\
\hline & 3.125 & 0 & 0 & 0 & 0 & 0 & .00 \\
\hline
\end{tabular}

Table 1B: Comparison of means of zone inhibition between aqueous and alcohol extracts against growth of Aspergillus niger at $50.0 \mathrm{~g} / \mathrm{ml}$ concentrations

\begin{tabular}{cccccc}
\hline Concentration $(\mathbf{g} / \mathrm{ml})$ & Group & Mean $(\mathrm{SD})$ & $\begin{array}{c}\text { Mean difference } \\
(95 \% \mathrm{Cl})\end{array}$ & t-statistic (df) & p-value \\
\hline \multirow{2}{*}{50.0} & Aqueous & $14.00(0.71)$ & $2.60(1.42,3.77)$ & $5.10(8)$ & 0.001 \\
& Alcohol & $11.40(0.89)$ & & & \\
\hline
\end{tabular}

Independent t-test was applied

Comparison on antifungal activity of kaffir lime leaf aqueous and alcohol extract against Aspergillus niger

Comparison between antifungal activity of KLL aqueous and alcohol extract against Aspergillus niger demonstrated that antifungal activity in aqueous KLL extract is better than alcohol KLL extract. In concentration $50 \mathrm{~g} / \mathrm{ml}$, zone of inhibition of aqueous KLL extract was bigger as compared to alcohol KLL extract (Table 1B). Independent t-test showed aqueous extracts has bigger mean of inhibition as compared to alcohol extract against Aspergillus niger $(\mathrm{p}<0.001)$. Ninety five percent confidence interval of mean difference of inhibition does not include zero. Therefore, statistically antifungal activity of Aspergillus niger is better in aqueous KLL extract than alcohol extract.

Inhibitory efficacy of kaffir lime leaf on Candida albicans

Candida albicans showed sensitivity to both aqueous and alcohol KLL extracts (Table 2A). Growth of Candida albicans was inhibited in KLL alcohol and aqueous extract concentrations of $50 \mathrm{~g} / \mathrm{ml}, 25 \mathrm{~g} / \mathrm{ml}$ and 


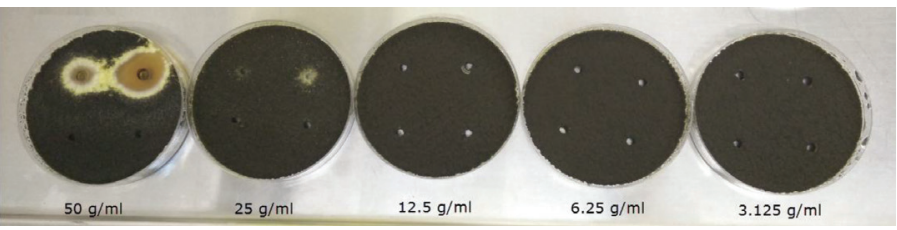

Figure 2A: One replicate of samples showing zone of inhibition of kaffir lime leaf extracts on Aspergillus niger growth at 5 different concentrations.

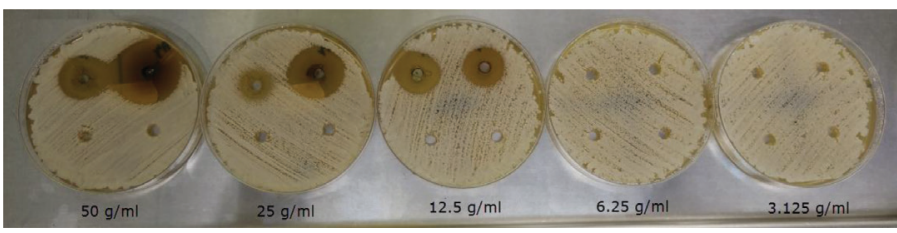

Figure 2B: One replicate of samples showing zone of inhibition of kaffir lime leaf extracts on Candida albicans growth at five different concentrations.

Table 2A: Measurement of zone of inhibition of alcohol and aqueous kaffir lime leaf extracts on Candida albicans growth at five different concentrations

\begin{tabular}{|c|c|c|c|c|c|c|c|}
\hline \multirow[t]{2}{*}{ Extracts } & \multirow[t]{2}{*}{ Concentration (g/ml) } & \multicolumn{5}{|c|}{ Zone of Inhibition (mm) } & \multirow[t]{2}{*}{ Mean $(\mathrm{mm})$} \\
\hline & & R1 & R2 & R3 & R4 & R5 & \\
\hline \multirow[t]{5}{*}{ Aqueous } & 50.000 & 26 & 27 & 28 & 27 & 28 & 27.20 \\
\hline & 25.000 & 16 & 17 & 18 & 17 & 18 & 17.20 \\
\hline & 12.500 & 10 & 11 & 12 & 10 & 12 & 11.00 \\
\hline & 6.250 & 0 & 0 & 0 & 0 & 0 & .00 \\
\hline & 3.125 & 0 & 0 & 0 & 0 & 0 & .00 \\
\hline \multirow[t]{5}{*}{ Alcohol } & 50.000 & 29 & 30 & 31 & 29 & 31 & 30.00 \\
\hline & 25.000 & 23 & 23 & 24 & 23 & 24 & 23.40 \\
\hline & 12.500 & 13 & 14 & 15 & 13 & 14 & 13.80 \\
\hline & 6.250 & 0 & 0 & 0 & 0 & 0 & .00 \\
\hline & 3.125 & 0 & 0 & 0 & 0 & 0 & .00 \\
\hline
\end{tabular}

Table 2B: Comparison of mean zone of inhibition against Candida albicans among three concentration groups in aqueous kaffir lime leaf extracts

\begin{tabular}{cccc}
\hline $\begin{array}{c}\text { Concentration of } \\
\text { extracts }(\mathbf{g} / \mathbf{m l})\end{array}$ & Mean (SD) & F-statistic (df) & p-value \\
\hline 50.0 & $27.20(0.84)$ & $417.58(2)$ & $<0.001$ \\
25.0 & $17.20(0.84)$ & & \\
12.5 & $11.00(1.00)$ & & \\
\hline
\end{tabular}

One-Way ANOVA test was applied

$12.5 \mathrm{~g} / \mathrm{ml}$. One replicate of samples at different concentrations whereby aqueous KLL extract tested at left upper quadrant of petri dish and alcohol KLL extract tested at right upper quadrant of each petri dish (Figure 2B). Mean zone of inhibition increase in proportion to extract concentration.

One-way ANOVA showed significant mean differences between groups of concentration for aqueous KLL extracts (Table 2B). Mean zone of inhibition of concentration $50 \mathrm{~g} / \mathrm{ml}$ was $27.20 \mathrm{~mm}, 25 \mathrm{~g} / \mathrm{ml}$ was 17.20 $\mathrm{mm}$ and $12.5 \mathrm{~g} / \mathrm{ml}$ was $11.00 \mathrm{~mm}$ with significant difference between the three groups $(\mathrm{p}<0.001)$. Post-hoc comparison showed significant difference in $50 \mathrm{~g} / \mathrm{ml}$ vs $25 \mathrm{~g} / \mathrm{ml}(\mathrm{p}<0.001), 50 \mathrm{~g} / \mathrm{ml}$ vs $12.5 \mathrm{~g} / \mathrm{ml}(\mathrm{p}<0.001)$ and $25 \mathrm{~g} / \mathrm{ml}$ vs $12.5 \mathrm{~g} / \mathrm{ml}(\mathrm{p}<0.001$ ) (Table $2 \mathrm{C}$ ). The higher KLL aqueous concentrations gave high effect to mean of inhibition of growth of Candida albicans.

One-way ANOVA also showed significant mean differences between groups of concentration for alcohol KLL extracts against Candida albicans (Table 2D). Mean zone of inhibition of concentration $50 \mathrm{~g} / \mathrm{ml}$ was $30.00 \mathrm{~mm}$, $25 \mathrm{~g} / \mathrm{ml}$ was $23.40 \mathrm{~mm}$ and $12.5 \mathrm{~g} / \mathrm{ml}$ was $13.80 \mathrm{~mm}$ with significant difference between the three groups $(\mathrm{p}<0.001)$. Post-hoc comparison showed significant difference in $50 \mathrm{~g} / \mathrm{ml}$ vs $25 \mathrm{~g} / \mathrm{ml}(\mathrm{p}<0.001), 50 \mathrm{~g} / \mathrm{ml}$
Table 2C: Post-hoc comparison of mean difference of zone of inhibition against Candida albicans among three concentration groups in aqueous kaffir lime leaf extracts

\begin{tabular}{ccc}
\hline $\begin{array}{c}\text { Concentration of extracts } \\
(\mathrm{g} / \mathrm{ml})\end{array}$ & $\begin{array}{c}\text { Mean difference } \\
(95 \% \text { Confidence Interval })\end{array}$ & p-value \\
\hline 50.0 vs 25.0 & $10.00(8.42,11.58)$ & $<0.001$ \\
50.0 vs 12.5 & $16.20(14.62,17.78)$ & $<0.001$ \\
25.0 vs 12.5 & $6.20(4.62,7.78)$ & $<0.001$ \\
\hline
\end{tabular}

aScheffe test was applied

Table 2D: Comparison of mean zone of inhibition against Candida albicans among three concentration groups in alcohol kaffir lime leaf extracts

\begin{tabular}{cccc}
\hline $\begin{array}{c}\text { Concentration of } \\
\text { extracts }(\mathbf{g} / \mathrm{ml})\end{array}$ & Mean (SD) & F-statistic (df) & p-value \\
\hline 50.0 & $30.00(1.00)$ & $497.70(2)$ & $<0.001$ \\
25.0 & $23.40(0.55)$ & & \\
12.5 & $13.80(0.84)$ & & \\
\hline
\end{tabular}

One-Way ANOVA test was applied

Table 2E: Post-hoc comparison of mean difference of zone of inhibition against Candida albicans among three concentration groups in alcohol kaffir lime leaf extracts

\begin{tabular}{ccc}
\hline $\begin{array}{c}\text { Concentration of extracts } \\
(\mathrm{g} / \mathrm{ml})\end{array}$ & $\begin{array}{c}\text { Mean difference } \\
(95 \% \text { Confidence Interval })\end{array}$ & p-value \\
\hline 50.0 vs 25.0 & $6.60(5.16,8.04)$ & $<0.001$ \\
50.0 vs 12.5 & $16.20(14.76,17.64)$ & $<0.001$ \\
25.0 vs 12.5 & $9.60(8.16,11.04)$ & $<0.001$ \\
\hline
\end{tabular}

aScheffe test was applied 
Table 2F: Comparison of means of zone inhibition between aqueous and alcohol extracts against growth of Candida albicans at three different concentrations

\begin{tabular}{cccccc}
\hline $\begin{array}{c}\text { Concentration } \\
(\mathrm{g} / \mathrm{ml})\end{array}$ & Group & Mean (SD) & $\begin{array}{c}\text { Mean difference } \\
(95 \% \mathrm{Cl})\end{array}$ & t-statistic (df) & p-value \\
\hline 50.0 & Aqueous & $27.20(0.84)$ & $-2.80(-4.14,-1.46)$ & $-4.80(8)$ & 0.001 \\
& Alcohol & $30.00(1.00)$ & & $-13.86(8)$ & $<0.001$ \\
25.0 & Aqueous & $17.20(0.84)$ & $-6.20(-7.23,-5.17)$ & & 0.001 \\
& Alcohol & $23.40(0.55)$ & & $-4.80(8)$ & \\
\hline
\end{tabular}

Independent t-test was applied

\begin{tabular}{|c|c|c|c|c|c|}
\hline Concentration & Group & Mean (SD) & $\begin{array}{l}\text { Mean difference } \\
\qquad(95 \% \mathrm{Cl})\end{array}$ & t-statistic (df) & $\mathrm{p}$-value \\
\hline \multirow[t]{2}{*}{$50.0 \mathrm{~g} / \mathrm{ml}$} & Aspergillus niger & $13.80(3.77)$ & $-13.40(-17.38,-9.41)$ & $-7.76(8)$ & $<0.001$ \\
\hline & Candida albicans & $27.20(0.84)$ & & & \\
\hline \multirow[t]{2}{*}{$25.0 \mathrm{~g} / \mathrm{ml}$} & Aspergillus niger & 0 & $-17.20(-18.06,-16.34)$ & $-45.97(8)$ & $<0.001$ \\
\hline & Candida albicans & $17.20(0.84)$ & & & \\
\hline \multirow[t]{2}{*}{$12.5 \mathrm{~g} / \mathrm{ml}$} & Aspergillus niger & 0 & $-11.00(-12.03,-9.97)$ & $-42.60(8)$ & $<0.001$ \\
\hline & Candida albicans & $11.00(1.00)$ & & & \\
\hline
\end{tabular}

Independent t-test was applied

Table 3B: Comparison of mean of zone inhibition against Candida albicans and Aspergillus niger on alcohol Kaffir lime leaves extract at three different concentrations

\begin{tabular}{|c|c|c|c|c|c|}
\hline Concentration & Group & Mean (SD) & $\begin{array}{l}\text { Mean difference } \\
\qquad(95 \% \mathrm{Cl})\end{array}$ & t-statistic (df) & $\mathrm{p}$-value \\
\hline \multirow[t]{2}{*}{$50.0 \mathrm{~g} / \mathrm{ml}$} & Aspergillus niger & $11.40(0.89)$ & $-18.60(-19.98,-17.22)$ & $-31.00(8)$ & $<0.001$ \\
\hline & Candida albicans & $30.00(1.00)$ & & & \\
\hline \multirow[t]{2}{*}{$25.0 \mathrm{~g} / \mathrm{ml}$} & Aspergillus niger & 0 & $-23.40(-23.96,-22.84)$ & $-95.53(8)$ & $<0.001$ \\
\hline & Candida albicans & $23.40(0.55)$ & & & \\
\hline \multirow[t]{2}{*}{$12.5 \mathrm{~g} / \mathrm{ml}$} & Aspergillus niger & 0 & $-13.80(-14.66,-12.94)$ & $-36.88(8)$ & $<0.001$ \\
\hline & Candida albicans & $13.80(0.84)$ & & & \\
\hline
\end{tabular}

Independent t-test was applied

vs $12.5 \mathrm{~g} / \mathrm{ml}(\mathrm{p}<0.001)$ and $25 \mathrm{~g} / \mathrm{ml}$ vs $12.5 \mathrm{~g} / \mathrm{ml}(\mathrm{p}<0.001)$ (Table 2E). Therefore, statistically one-way ANOVA showed significant mean differences between group of concentration for both alcohol and aqueous KLL extracts against Candida albicans with $\mathrm{p}<0.001$.

\section{Comparison on antifungal activity of kaffir lime leaf aqueous and alcohol extract against Candida albicans}

Comparison between antifungal activity of KLL aqueous and alcohol extract against Candida albicans demonstrated that both alcohol and aqueous KLL extracts showed significant antifungal activities towards Candida albicans with widest zone of inhibition was $30 \mathrm{~mm}$ in alcohol extract. Antifungal activity in alcohol KLL extract is better than aqueous KLL extract. In each concentration of $50 \mathrm{~g} / \mathrm{ml}, 25 \mathrm{~g} / \mathrm{ml}$ and $12.5 \mathrm{~g} / \mathrm{ml}$, zone of inhibition alcohol extracts was more as compared to aqueous extracts (Table 2F). Independent t-test showed that alcohol extracts has bigger mean of inhibition as compared to aqueous extract in all three concentrations against Candida albicans $(\mathrm{p}<0.001)$. Ninety five percent confidence interval of mean difference of inhibition does not include zero. Therefore, statistically antifungal activity of Candida albicans is better in alcohol KLL extract than aqueous extract.

\section{Comparison on antifungal activity of kaffir lime leaf} between Candida albicans and Aspergillus niger

Comparison on antifungal activity of KLL between Candida albicans and Aspergillus niger were done using independent t-test (Table 3A). Candida albicans was inhibited better as compared to Aspergillus niger in aqueous KLL extracts with significant $\mathrm{p}<0.001$ for all three concentrations. Candida albicans also was inhibited better as compared to Aspergillus niger in alcohol extract. Comparison with significant difference was observed (Table 3B). Both the MIC of KLL aqueous extract against Candida albicans was $12.02 \mathrm{~g} / \mathrm{ml}$, KLL alcohol extract against Candida albicans was 10.23 $\mathrm{g} / \mathrm{ml}$, KLL aqueous extract against Aspergillus niger was $47.86 \mathrm{~g} / \mathrm{ml}$ and KLL alcohol extract against Aspergillus niger was $48.97 \mathrm{~g} / \mathrm{ml}$. Figure 3

\section{DISCUSSION}

In this study, both alcoholic and aqueous extract of KLL showed significant antifungal activities against Candida albicans and Aspergillus niger. The efficacy of antifungal towards the pathogenic otomycosis was noted solvent dependant. Candida albicans was inhibited better as compared to Aspergillus niger in both aqueous and alcohol KLL extracts. 

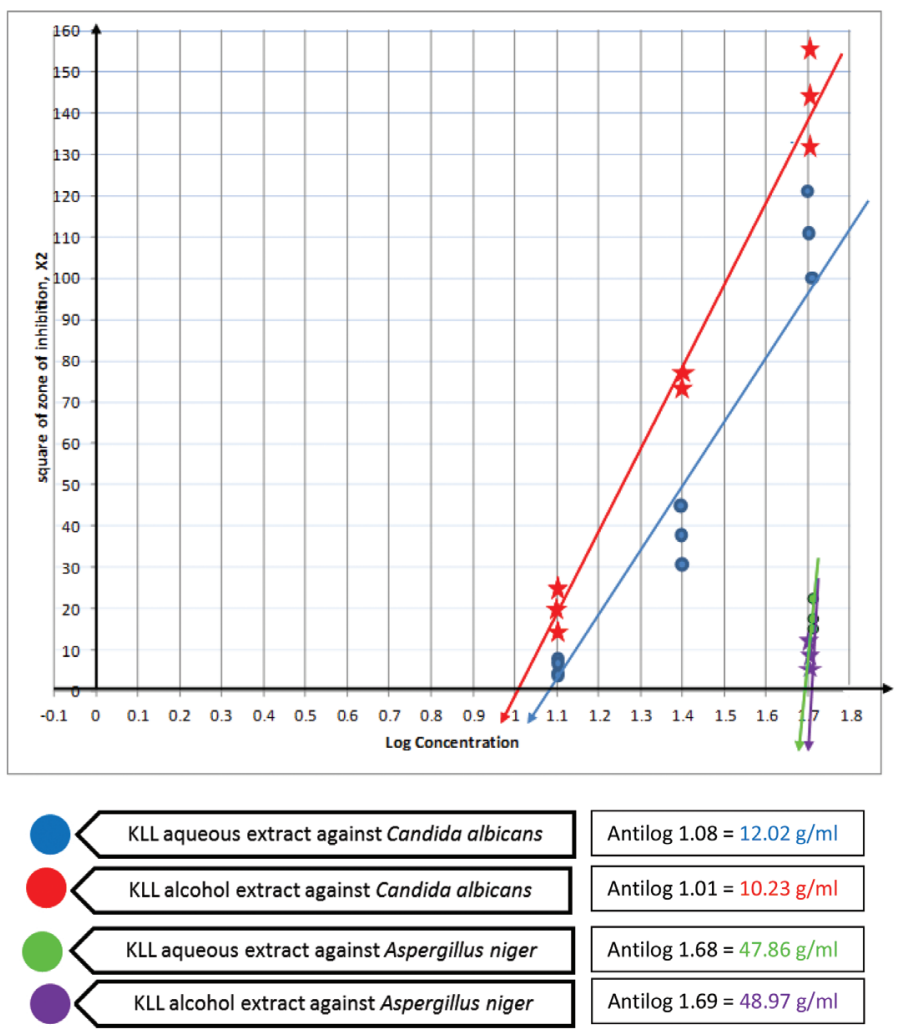

Figure 3: Scattered plot graph with linear line showing zone of inhibition of different concentrations of aqueous and ethanol Kaffir lime leaves extracts against Candida albicans and Aspergillus niger.

Antifungal activity of Candida albicans in alcoholic extracts is more remarkable than in aqueous extract. The MIC of KLL aqueous extract against Candida albicans was $12.02 \mathrm{~g} / \mathrm{ml}$ and MIC KLL alcoholic extract was $10.23 \mathrm{~g} / \mathrm{ml}$. Therefore, there was more inhibition in alcoholic extract as compared to aqueous extract. There are several studies which has shown presence of zone of inhibition of the KLL extract towards Candida albicans including study by Binawati Ginting on antifungal activity of essential oils from leaves of Wedelia biflora, leaves of Citrus hystrix D.C (Kaffir lime), leaves of Ocimum basilicum L., and flower Caesalpinia pulcherima L. at different concentrations against Candida albicans. The author used aqueous extract and she discovered that aqueous extract of KLL gives the best antifungal activity against Candida albicans with a concentration of $10 \%, 5 \%$ and $1 \%$ respectively show the average of the inhibition zone by $24.5 \mathrm{~mm}, 23 \mathrm{~mm}$ and $10 \mathrm{~mm} .{ }^{17}$ Higher concentration give higher percentage of inhibition. ${ }^{17}$ However there is no data on efficacy of ethanol extract of KLL in her study. In our study, antifungal activity of Candida albicans is better in alcohol extract than aqueous extract of KLL $(\mathrm{p}<0.001)$. The better effectiveness of the alcohol extract of KLL may be due to difference in constituent of extraction, which was due to the substantial amounts of polar constitutes from the plant material. ${ }^{18}$ Alcohol extracts have low polarity as compared to aqueous. ${ }^{18}$ In addition to that, the difference in antifungal activities attributed to presence of active principles that are extracted by different solvents, which may be influenced by several factors such as age of plant, method of extraction and type of extracting solvent. ${ }^{19}$

As for Aspergillus niger, we noted there was antifungal activity towards Aspergillus niger but it was more remarkable in aqueous KLL extract as compared to alcoholic KLL extract, a total opposite to Candida albicans. Not many literatures mentioned on antifungal effect of KLL towards
Aspergillus niger. Unlike Candida albicans, Aspergillus niger does not exhibit biofilm formation or adhesion composite resin. Some of the selected Aspergillus spp. are known to produce secondary metabolites or toxic substances that are capable of eliciting toxicity in animals and human. ${ }^{20}$ The pathogenicity of Aspergillus spp. closely related to these mycotoxins. Study by Thanaboripat et al. revealed that KLL extract at all concentrations had significant inhibitory effect on the fungal growth of Aspergillus flavus $(\mathrm{p}<0.001)$. Aspergillus flavus has the capability of producing toxic secondary metabolites, known as aflatoxin. ${ }^{21}$ Although Aspergillus niger does not have the ability to produce aflatoxin, this fungal produce almost similar mycotoxin such as 3-nitropropionic acid and ochratoxin A. ${ }^{20,21}$ Possible explanation regarding inhibition more in aqueous extract rather than alcoholic is depending on the bioactive constituent in the extract. Extraction using water as solvent will preserve certain substance which will strongly inhibit Aspergillus niger growth. Rammanee and Hongpattarakere evaluated on inhibitory activities of ethyl acetate extracts and hydrodistillated essential oils from five cultivars of tropical citrus epicarps against Aspergillus fumigatus, Aspergillus niger, Aspergillus flavus, Aspergillus parasiticus, and Penicillium sp. Among all citrus cultivars, only extract from kaffir lime inhibited the growth of all fungi tested. The result appeared to be more sensitive to the hydrodistillated oil than the ethyl acetate extract which suggestive that fungal growth inhibition is solvent dependent. ${ }^{22}$ In our study, antifungal activity of Aspergillus niger is better in aqueous KLL extract than alcohol extract $(\mathrm{p}<0.001)$. Despite of using hydrodistillated oil, we used other aqueous base extraction method using soxhlet apparatus that showed almost similar result.

Kaffir lime contained multiple antimicrobial compounds with major constituents of citronellol, limonene, linalool, and o-cymene, correlating to its broad-spectrum inhibition. ${ }^{26}$ Combinations of limonene with other components such as citronellol and linalool may be responsible for the antifungal activity of kaffir lime because they were present in the significant level. In addition, many other minor compounds such as o-cymene, sabinene, $\beta$-myrcene, $\beta$-pinene, and $\alpha$-pinene should not be ignored. ${ }^{22}$ The antimicrobial activity of these compounds was previously reported. Pure limonene at a concentration of $25 \mu \mathrm{l} / \mathrm{l}$ was reported to effectively inhibit Fusarium verticillioides. ${ }^{23} \mathrm{P}$-cymene has strong mycelial growth inhibition towards F. oxysporum and can cause destabilization of B. cereus cytoplasmic membrane. ${ }^{24}$ Other monoterpenes including citronellol, limonene, $\beta$-myrcene, $\beta$-pinene, $\alpha$-pinene, and $\alpha$-terpineol able to inhibit hyphae growth. ${ }^{25}$ Also, citronellal and citronellol were reported to effectively inhibit human pathogenic fungus, Microsporum gypseum, which is known to cause hair and scalp infections. ${ }^{26}$ Therefore, the inhibitory activity was contributed from the synergistic effect of both major and minor constituents present in the kaffir lime.

\section{CONCLUSION}

KLL showed that the leaves extracts possessed remarkable antifungal activity against all tested fungi, evidenced by presence of zone of inhibition in both extracts for both fungi growth. Antifungal activity of Aspergillus niger is better in aqueous KLL extract than alcohol extract. In contrast, antifungal activity of Candida albicans is better in alcohol KLL extract than aqueous extract. Candida albicans was inhibited better as compared to Aspergillus niger in both aqueous and alcohol KLL extract. We would suggest that KLL able to achieve medical use as ototopical antifungal with low risk of ototoxicity. Furthermore, with easy availability of KLL in Malaysia, it can be cheap and environmental friendly source of medication.

\section{Disclosure of funding}

Usains Research Grant and USM Short Term Grant. 


\section{CONFLICT OF INTEREST}

The authors are declared no conflict of interest.

\section{REFERENCES}

1. Abirami A, Nagarani G, Siddhuraju P. The medicinal and nutritional role of underutilized citrus fruit-Citrus hystrix (Kaffir Lime): A Review. Drug Invent Today. 2014;6(1):1-5.

2. Hutadilok-Towatana N. Chaiyamutti P, Panthong K, Mahabusarakam W, Rukachaisirikul V. Antioxidative and free radical scavenging activities of some plants used in Thai folk medicine. Pharm. Biol. 2006;44(3):221-8.

3. Lertsatitthanakorn P, Taweechaisupapong S, Aromdee C, Khunkitti W. In vitro bioactivities of essential oils used for acne control. Int. J. Aroma. 2006;16(1):43-9.

4. Srisukha V, Tribuddharatb C, Nukoolkarnc V, Bunyapraphatsarac N, Chokephaibulkitd, Phoomniyomb KS, et al. Antibacterial activity of essential oils from Citrus hystrix (makrut lime) against respiratory tract pathogens. Science Asia. 2012;38:212-7.

5. Jing L, Lei Z, Li L, Xie R, XiW, Guan Y, et al. Antifungal activity of citrus essential oils. J. Agric. Food. Chem. 2014;62(14):3011-33.

6. Chueahongthong F, Ampasavate C, Okonogi S, Tima S, Anuchapreeda S. Cytotoxic effects of crude kaffir lime (Citrus hystrix, DC.) leaf fractional extracts on leukemic cell lines. J. Med. Plants Res. 2011;5(14):3097-105.

7. Lawrence BM, Hogg JW, Terhune SJ, Podimuang V. Constituents of the leaf and peel oils of Citrus hystrix, DC. Phytochemistry. 1971;10(6):1404-5.

8. Tinjan $P$, Jirapakkul W. Comparative study on extraction methods of free and glycosidically bound volatile compounds from kaffir lime leaves by solvent extraction and solid phase extraction. Kasetsart Journal. 2007;41:300-6.

9. Rammanee K, Hongpattarakere T. Effects of tropical citrus essential oils on growth, aflatoxin production, and ultrastructure alterations of Aspergillus flavus and Aspergillus parasiticus. Food Bioprocess Tech. 2011;4(6):1050-9.

10. Munguia R, Daniel SJ. Ototopical antifungals and otomycosis: a review. Inter J Pediatric Otorhinolaryngology. 2008;72(4):453-9.

11. Chin CS, Jegathesan M. Fungal isolates in otomycosis. Malays J Pathology. 1982;5:45

12. Samson RA, Visagie CM, Houbraken J, Hong SB, Hubka V, Klaassen CH, et al. Phylogeny, identification and nomenclature of the genus Aspergillus. Stud Mycol. 2014; 78:141-73
13. Kuhn DM, Ghannoum MA. Candida biofilms: Antifungal resistance and emerging therapeutic options. Current Opinion. Invest. Drugs. 2004;5(2):186-97.

14. Munguia R, Daniel SJ. Ototopical antifungals and otomycosis: A review. Inter J Pediatric Otorhinolaryngology. 2008;72(4):453-9.

15. Vennewald I, Klemm E. Otomycosis: Diagnosis and treatment. Clinics Dermatology. 2010;28(2):202-11.

16. Saniasaya J, Salim R, Mohamad I, Harun A. Antifungal effect of Malaysian Aloe Vera leaf extract on selected fungal species causing otomycosis in in-vitro culture medium. Oman Med J. 2017;32(1):41-6.

17. Ginting B. Antifungal activity of essential oils some plants in Aceh province against Candida albicans. Journal Natural. 2012;12(2):18-22.

18. Shekhawat PS, Prasada R. Antifungal properties of some plant extracts. Inhibition of spore germination. Indian Phytopathology. 1991;24;800-2. (1972)

19. Schmutterer $\mathrm{H}$, Ascher KRS. Natural pesticides from the neem tree (Azadirachta indica A. Juss) and other tropical plants. Proceedings of the Second International Neem Conference, Rauischholzhausen, Federal Republic of Germany. 1983;25-28

20. Schuster E, Dunn-Coleman N, Frisvad JC, Dijck P. On the safety of Aspergillus Niger-a review. Appl. Microbiology. Biotechnology. 2002;59(4-5):426-35.

21. Thanaboripat $D$, Suvathi $Y$, Srilohasin $P$, Sripakdee $S$, Patthanawanitchai $O$, Charoensettasilp S. Inhibitory effect of essential oils on the growth of Aspergillus flavus. KMITL. Sci Tech J. 2007;6(1):18-24. (2007;7(1):1-7)

22. Rammanee $K$, Hongpattarakere $T$. Effects of tropical citrus essential oils on growth, aflatoxin production, and ultrastructure alterations of Aspergillus flavus and Aspergillus parasiticus Food Bioprocess. Technol. 2011;4(6):1050-9.

23. Dambolena JS, López AG, Cánepa MC, Theumer MG, Zygadlo JA, Rubinstein HR Inhibitory effect of cyclic terpenes (limonene, menthol, menthone and thymol) on Fusarium verticillioides MRC 826 growth and fumonisin B1 biosynthesis. Toxicon. 2008;51(1):37-44.

24. Ultee A, Bennik MH, Moezelaar R. The phenolic hydroxyl group of carvacrol is essential for action against the food-borne pathogen Bacillus cereus. Appl. Environ. Microbiology. 2002;68(4):1561-8.

25. Yamasaki Y, Kunoh H, Yamamoto H, Akimitsu K. Biological roles of monoterpene volatiles derived from rough lemon (Citrus jambhiri Lush) in citrus defense. J Gen Plant Pathology. 2007;73(3):168-79.

26. Samy RP. Antimicrobial activity of some medicinal plants from India. Fitoterapia. $2005 ; 76(7): 697-9$.

Article History: Submission Date : 02-06-2017 ; Revised Date : 15-07-2017; Acceptance Date : 31-07-2017.

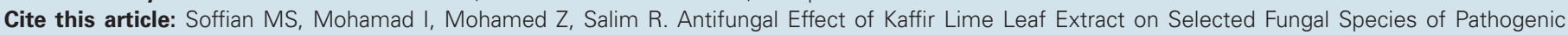
Otomycosis in in vitro Culture Medium. J Young Pharm. 2017;9(4):468-74. 